Pacific Northwest National Laboratory

Operated by Battelle for the U.S. Department of Energy

\title{
First Quarter Seismic Report for Fiscal Year 2006
}

Pacific Northwest National Laboratory

Hanford Seismic Assessment Team

A. C. Rohay

S. P. Reidel

D. C. Hartshorn

M. D. Sweeney

R. E. Clayton

September 2006

Prepared for the U.S. Department of Energy under Contract DE-AC05-76RL01830 


\title{
DISCLAIMER
}

This report was prepared as an account of work sponsored by an agency of the United States Government. Reference herein to any specific commercial product, process, or service by trade name, trademark, manufacturer, or otherwise does not necessarily constitute or imply its endorsement, recommendation, or favoring by the United States Government or any agency thereof, or Battelle Memorial Institute.

\author{
PACIFIC NORTHWEST NATIONAL LABORATORY \\ operated by \\ BATTELLE \\ for the \\ UNITED STATES DEPARTMENT OF ENERGY \\ under Contract DE-AC05-76RL01830
}

\author{
Printed in the United States of America \\ Available to DOE and DOE contractors from the \\ Office of Scientific and Technical Information, P.O. Box 62, Oak Ridge, TN 37831: \\ prices available from (615) 576-8401. \\ Available to the public from the National Technical Information Service, \\ U.S. Department of Commerce, 5285 Port Royal Rd., Springfield, VA 22161
}

This document was printed on recycled paper. 


\title{
First Quarter Seismic Report for Fiscal Year 2006
}

\author{
A. C. Rohay \\ S. P. Reidel \\ D. C. Hartshorn \\ M. D. Sweeney \\ R. E. Clayton
}

September 2006

Prepared for

the U.S. Department of Energy

under Contract DE-AC05-76RL01830

Pacific Northwest National Laboratory

Richland, Washington 99352 


\section{Summary}

Hanford Seismic Assessment (HSA) provides an uninterrupted collection of high-quality raw and processed seismic data from the Hanford Seismic Network for the U.S. Department of Energy and its contractors. The Hanford Seismic Assessment Team locates and identifies sources of seismic activity and monitors changes in the historical pattern of seismic activity at the Hanford Site. The data are compiled, archived, and published for use by the Hanford Site for waste management, Natural Phenomena Hazards assessments, and engineering design and construction. In addition, the seismic monitoring organization works with the Hanford Site Emergency Services Organization to provide assistance in the event of a significant earthquake on the Hanford Site.

The Hanford Seismic Network and the Eastern Washington Regional Network consist of 41 individual sensor sites and 15 radio relay sites maintained by the Hanford Seismic Assessment Team.

For the Hanford Seismic Network, there were 57 local earthquakes for the first quarter of fiscal year 2006. The largest earthquake for the quarter was a magnitude 2.6 event on November 10, 2005. This earthquake was a random event and occurred in the crystalline basement beneath the Horse Heaven Hills. Stratigraphically, 46 earthquakes occurred in the Columbia River basalt (approximately 0-5 km), 6 earthquakes were in the pre-basalt sediments (approximately 5-10 km), and 5 earthquakes were in the crystalline basement (approximately 10-25 km). Geographically, 50 earthquakes occurred in swarm areas, no earthquakes were on major geologic structures, and 7 earthquakes were classified as random

events. The most significant event was the occurrence of 39 earthquakes at the eastern end of the Coyote Rapids Swarm Area at the 'horn' of the Columbia River. 


\section{Acronyms}

\begin{tabular}{|c|c|}
\hline BWIP & Basalt Waste Isolation Project \\
\hline CDPD & Cellular Digital Packet Data \\
\hline CRBG & Columbia River Basalt Group \\
\hline DOE & U.S. Department of Energy \\
\hline ETNA & strong motion accelerometer manufactured by Kinemetrics \\
\hline EWRN & Eastern Washington Regional Network \\
\hline FY & fiscal year \\
\hline GPS & Global Positioning System \\
\hline HSA & Hanford Seismic Assessment \\
\hline HSN & Hanford Seismic Network \\
\hline $\mathrm{M}_{\mathrm{c}}$ & Coda-Length Magnitude \\
\hline $\mathrm{M}_{\mathrm{L}}$ & Local Magnitude \\
\hline $\mathrm{M}_{\mathrm{w}}$ & Moment Magnitude \\
\hline PNNL & Pacific Northwest National Laboratory \\
\hline RAW & Rattlesnake Mountain-Wallula Alignment \\
\hline SMA & strong motion accelerometer \\
\hline USGS & United States Geological Survey \\
\hline UTC & Universal Time, Coordinated \\
\hline UW & University of Washington \\
\hline WHC & Westinghouse Hanford Company \\
\hline
\end{tabular}




\section{Contents}

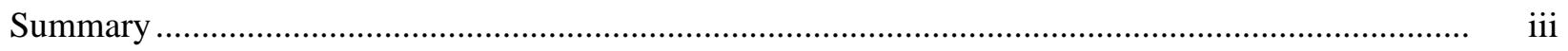

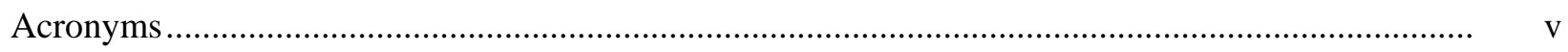

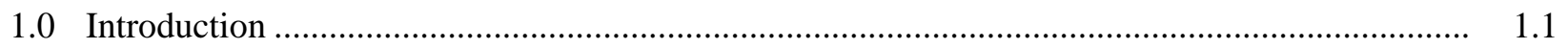

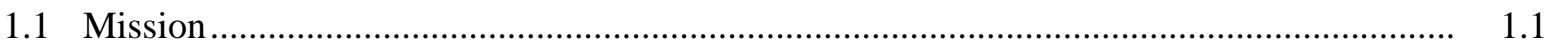

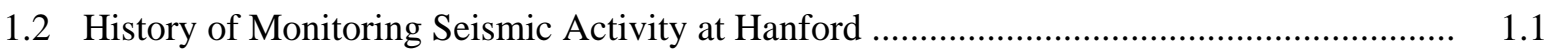

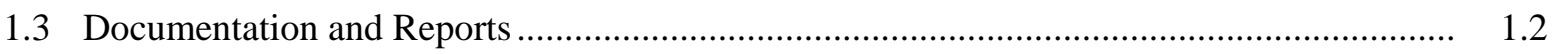

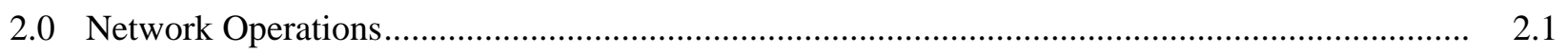

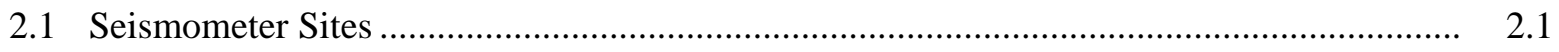

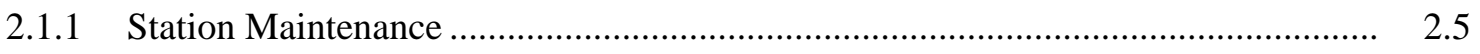

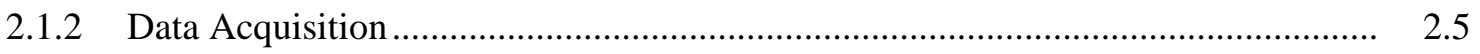

2.2 Strong Motion Accelerometer Sites ............................................................................ 2.5

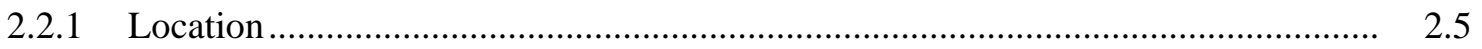

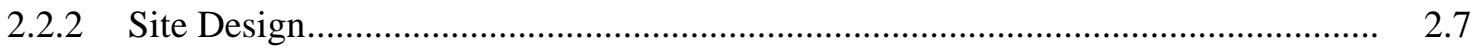

2.2.3 Strong Motion Accelerometer Operations Center ................................................ 2.8

2.2.4 Strong Motion Operational Characteristics ............................................................. 2.8

3.0 Earthquake Catalog Description ...........................................................................................

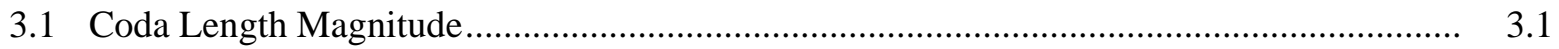

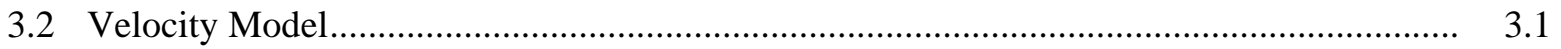

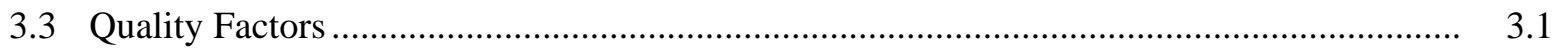

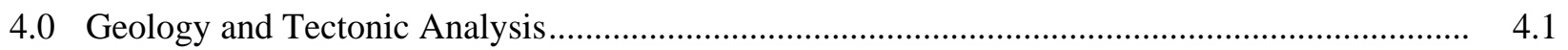

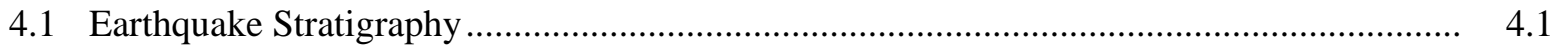

4.2 Geologic Structure Beneath the Monitored Area .......................................................... 4.1

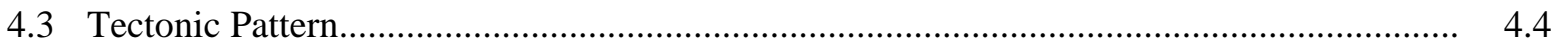

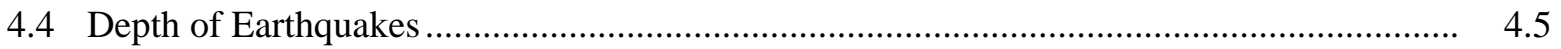

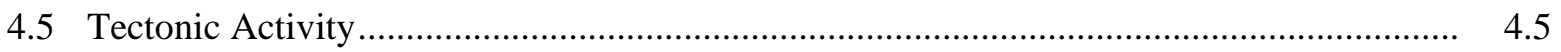

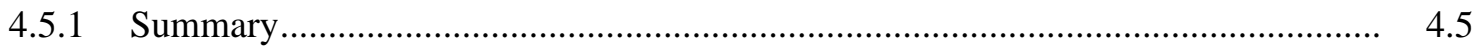

4.5.2 First Quarter Earthquakes of FY 2006............................................................. 4.6

5.0 Strong Motion Accelerometer Operations ............................................................................... 5.1

5.1 FY 2006 Triggers of the Hanford SMA Network ............................................................ 5.1

6.0 Capabilities in the Event of a Significant Earthquake ............................................................... 6.1

6.1 Use of the SMA Network in the Event of an Earthquake .................................................... 6.1

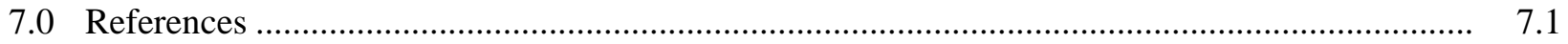




\section{Figures}

2.1 Locations of Seismograph Stations and Strong Motion Accelerometer Sites in the Hanford Seismic Network ............................................................................................... 2.2

2.2 Locations of Seismograph Stations in the Eastern Washington Regional Network.................... 2.4

2.3 Schematic Diagram of a Strong Motion Accelerometer Installation......................................... 2.8

4.1 Tectonic Map of Columbia Basin Showing Major Seismic Source Structures ........................... 4.2

4.2 Geologic Cross Sections Through the Columbia Basin ..........................................................

4.3 All Earthquakes Recorded Within the Hanford Monitoring Area during the First Quarter

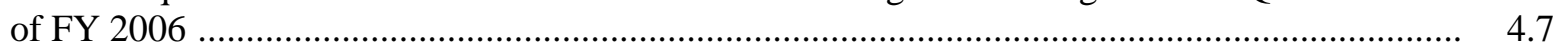

4.4 Timing of Earthquakes in the Coyote Rapids Earthquake Swarm during the First Quarter

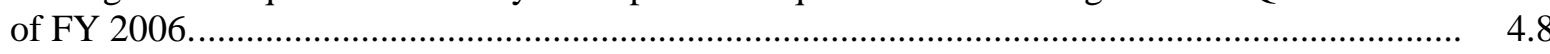

\section{Tables}

2.1 Seismic Stations in the Hanford Seismic Network ............................................................. 2.1

2.2 Seismic Stations in the Eastern Washington Regional Network .............................................. 2.3

3.1 Local Seismic Data, October 1, 2005 to December 31, 2005 ................................................... 3.2

3.2 Seismic Velocities for Columbia Basin Stratigraphy ............................................................ 3.6

4.1 Thicknesses of Stratigraphic Units in the Monitoring Area ...................................................... 4.4

4.2 Number of Local Earthquakes Occurring in Stratigraphic Units .............................................. 4.5

4.3 Summary of Earthquake Locations for FY 2005 ...................................................................... 


\subsection{Introduction}

This report covers the locations of seismicity within the Hanford monitoring region of south-central Washington for the first quarter of fiscal year (FY) 2006, and provides geologic interpretations of those earthquakes.

\subsection{Mission}

The principal mission of Hanford Seismic Assessment (HSA) is to ensure compliance with DOE Order 420.1, "Facility Safety" and DOE Order G 420.1-1, Section 4.7, "Emergency Preparedness and Emergency Communications.” DOE Order 420.1 establishes facility safety requirements related to nuclear safety design, criticality safety, fire protection, and natural phenomena hazards mitigation. For seismic assessment, this order states:

\subsubsection{Natural Phenomena Detection.}

Facilities or sites with hazardous materials shall have instrumentation or other means to detect and record the occurrence and severity of seismic events.

The HSA supports Hanford Site emergency services organizations in complying with DOE Order G 420.1-1, Section 4.7, "Emergency Preparedness and Emergency Communications,” by providing assistance in the event of an earthquake on the Hanford Site.

In addition, the HSA provides an uninterrupted collection of high-quality raw seismic data from the Hanford Seismic Network (HSN) located on and around the Hanford Site, and the Eastern Washington Regional Network (EWRN). This report provides interpretations of seismic events from the Hanford Site and vicinity. HSA locates and identifies sources of seismic activity, monitors changes in the historical pattern of seismic activity at the Hanford Site, and builds a "local” earthquake database (processed data) that is permanently archived. The focus of this report is the precise location of earthquakes proximal to or on the Hanford Site, specifically between 46 degrees and 47 degrees north latitude and between 119 degrees and 120 degrees west longitude. Data from the EWRN and other seismic networks in the northwest provide the HSA with necessary regional input for the seismic hazards analysis at the Hanford Site. These seismic data are used to support Hanford Site contractors for waste management activities, Natural Phenomena Hazards assessments, and engineering design and construction.

\subsection{History of Monitoring Seismic Activity at Hanford}

Assessing seismic activity at the Hanford Site was initiated in 1969 by the United States Geological Survey (USGS) under a contract with the U.S. Atomic Energy Commission. In 1975, the University of Washington (UW) assumed responsibility for the network and subsequently expanded it. In 1979, the Basalt Waste Isolation Project (BWIP) became responsible for collecting seismic data for the Hanford Site as part of site characterization activities. Rockwell Hanford Operations, followed by Westinghouse Hanford Company (WHC), operated the local network and were the contract technical advisors for the EWRN operated and maintained by UW. Funding ended for BWIP in December 1988. Assessment of seismic activity and responsibility for the UW contract were then transferred to WHC's Environmental Division. Maintenance responsibilities for the EWRN also were assigned to WHC who made major upgrades to EWRN sites. 
Effective October 1, 1996, all seismic assessment activities were transferred to the Pacific Northwest National Laboratory (PNNL). ${ }^{1}$

The Hanford Strong Motion Accelerometer (SMA) network was constructed during 1997 and came on-line in May 1997. It operated until September 30, 1997, when it was mothballed due to lack of funding. Funding was restored on October 1, 1998, by joint agreement between the U.S. Department of Energy (DOE) and PNNL. Operation of the SMA sites resumed on November 20, 1999, and has operated continuously since that time.

\subsection{Documentation and Reports}

The HSA issues quarterly reports of local activity, an annual catalog of earthquake activity on and near the Hanford Site, and special-interest bulletins on local seismic events. The HSA also provides information and special reports to other functions as requested. Earthquake information provided in these reports is subject to revisions if new data become available. In addition, an archive of all seismic data from the HSN is maintained by PNNL.

\footnotetext{
${ }^{1}$ Pacific Northwest National Laboratory is operated by Battelle Memorial Institute for the U.S. Department of Energy.
} 


\subsection{Network Operations}

\subsection{Seismometer Sites}

The seismic network consists of two designs of equipment and sites: seismometer sites and strong motion accelerometer (SMA) sites. Seismometer sites are designed to locate earthquakes and determine their magnitudes and hypocenter locations. SMA sites are designed to measure ground motion and are discussed in Section 2.2.

The Hanford Seismic Network (HSN) and the Eastern Washington Regional Network (EWRN) consist of 41 sensor sites. Most sites are in remote locations and require solar panels and batteries for power. The HSN uses 23 sites (Table 2.1 and Figure 2.1) and the EWRN uses 36 sites (Table 2.2 and Figure 2.2); both networks share 18 sites. The networks have 45 combined data channels because Gable Butte and Frenchman Hills East are three-component sites, each consisting of one vertical, one north-south horizontal, and one east-west horizontal data channel. Both networks use 15 additional telemetry relay sites. Data from all sites or relays are transmitted to the Sigma V building, Richland, Washington.

Table 2.1. Seismic Stations in the Hanford Seismic Network

\begin{tabular}{|c|c|c|c|c|}
\hline Station & $\begin{array}{c}\text { Latitude } \\
\text { Deg. Min. N }\end{array}$ & $\begin{array}{c}\text { Longitude } \\
\text { Deg. Min. W }\end{array}$ & Elevation (m) & Station Name \\
\hline BEN & $46 N 31.13$ & 119W43.02 & 340 & Benson Ranch \\
\hline BLT & $45 N 54.91$ & 119W10.55 & 659 & Bickelton \\
\hline BRV & $46 N 49.12$ & 119W59.47 & 920 & Black Rock Valley \\
\hline BVW & $46 N 48.66$ & 119W52.99 & 670 & Beverly \\
\hline CRF & $46 N 49.50$ & 119W23.22 & 189 & Corfu \\
\hline ET3 & 46N34.64 & 118W56.25 & 286 & Eltopia Three \\
\hline *FHE & 46N57.11 & 119W29.82 & 455 & Frenchman Hills East \\
\hline$*$ GBB & $46 N 36.49$ & 119W37.62 & 177 & Gable Butte \\
\hline GBL & 46N35.92 & 119W27.58 & 330 & Gable Mountain \\
\hline $\mathrm{H} 2 \mathrm{O}$ & $46 \mathrm{~N} 23.75$ & 119W25.38 & 158 & Water \\
\hline LOC & $46 \mathrm{~N} 43.02$ & 119W25.85 & 210 & Locke Island \\
\hline MDW & 46N36.79 & 119W45.66 & 330 & Midway \\
\hline MJ2 & $46 N 33.45$ & 119W21.54 & 146 & May Junction Two \\
\hline OT3 & $46 \mathrm{~N} 40.14$ & 119W13.98 & 322 & Othello Three \\
\hline PRO & $46 \mathrm{~N} 12.73$ & 119W41.15 & 550 & Prosser \\
\hline RED & 46N17.92 & 119W26.30 & 366 & Red Mountain \\
\hline RSW & 46N23.67 & 119W35.48 & 1,045 & Rattlesnake Mountain \\
\hline SNI & 46N27.85 & 119W39.60 & 312 & Snively Ranch \\
\hline VT2 & $46 N 58.04$ & 120W58.95 & 1,270 & Vantage Two \\
\hline WA2 & 46N45.32 & 119W33.94 & 244 & Wahluke Slope \\
\hline WIW & $46 \mathrm{~N} 25.76$ & 119W17.26 & 128 & Wooded Island \\
\hline WRD & $46 N 58.20$ & 119W08.69 & 375 & Warden \\
\hline YPT & 46N02.93 & 118W57.73 & 325 & Yellepit \\
\hline
\end{tabular}




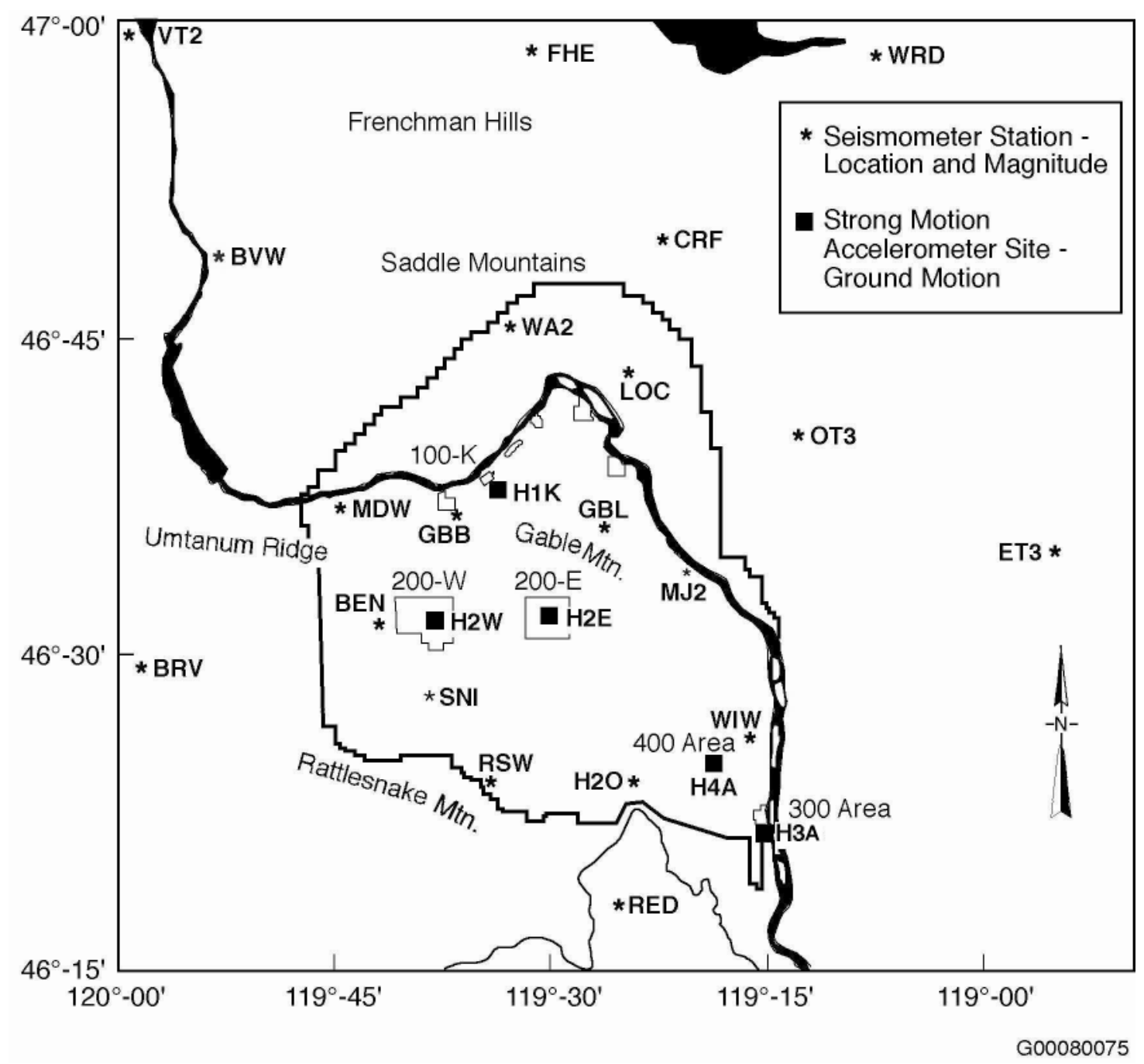

Figure 2.1. Locations of Seismograph Stations and Strong Motion Accelerometer Sites in the Hanford Seismic Network (see Tables 2.1 and 2.4 for description of locations). Bickelton (BLT), Prosser (PRO), Yellepit (YPT) are shown on Figure 2.2. 
Table 2.2. Seismic Stations in the Eastern Washington Regional Network

\begin{tabular}{|c|c|c|c|c|}
\hline Station & $\begin{array}{c}\text { Latitude } \\
\text { Deg. Min. N. }\end{array}$ & $\begin{array}{c}\text { Longitude } \\
\text { Deg. Min. W. }\end{array}$ & Elevation (m) & Station Name \\
\hline BLT & $46 \mathrm{~N} 54.91$ & 119W10.55 & 659 & Bickelton \\
\hline BRV & $46 N 29.12$ & 119W59.47 & 920 & Black Rock Valley \\
\hline BVW & $46 N 48.66$ & 119W52.99 & 670 & Beverly \\
\hline CBS & 47N48.26 & 120W02.50 & 1,067 & Chelan Butte, South \\
\hline CRF & $46 N 49.50$ & 119W23.22 & 189 & Corfu \\
\hline DPW & 47N52.25 & 118W12.17 & 892 & Davenport \\
\hline DY2 & $47 N 59.11$ & 119W46.28 & 890 & Dyer Hill Two \\
\hline ELL & 46N54.58 & 120W33.98 & 789 & Ellensburg \\
\hline EPH & 47N21.38 & 119W35.76 & 661 & Ephrata \\
\hline ET3 & 46N34.64 & 118W56.25 & 286 & Eltopia Three \\
\hline ETW & 47N36.26 & 120W19.94 & 1,477 & Entiat \\
\hline *FHE & 46N57.11 & 119W29.82 & 455 & Frenchman Hills East \\
\hline GBL & $46 N 35.92$ & 119W27.58 & 330 & Gable Mountain \\
\hline LNO & 45N52.31 & 118W17.11 & 771 & Lincton Mountain, Oregon \\
\hline LOC & $46 N 43.02$ & 119W25.85 & 210 & Locke Island \\
\hline MDW & 46N36.79 & 119W45.66 & 330 & Midway \\
\hline MJ2 & 46N33.45 & 119W21.54 & 146 & May Junction Two \\
\hline MOX & 46N34.64 & 120W17.89 & 501 & Moxee City \\
\hline NAC & 46N43.99 & 120W49.42 & 728 & Naches \\
\hline NEL & $48 N 04.21$ & 120W20.41 & 1,500 & Nelson Butte \\
\hline OD2 & $47 N 23.26$ & 118W42.58 & 553 & Odessa Two \\
\hline OT3 & 46N40.14 & 119W13.98 & 322 & Othello Three \\
\hline PAT2 & 45N53.03 & 119W45.40 & 259 & Paterson Two \\
\hline PRO & 46N12.73 & 119W41.15 & 550 & Prosser \\
\hline RSW & $46 \mathrm{~N} 23.67$ & 119W35.48 & 1,045 & Rattlesnake Mountain \\
\hline SAW & $47 N 42.10$ & 119W24.03 & 701 & St. Andrews \\
\hline TBM & $47 \mathrm{~N} 10.20$ & 120W35.88 & 1,006 & Table Mountain \\
\hline TRW & 46N17.32 & 120W32.31 & 723 & Toppenish Ridge \\
\hline TWW & 47N08.29 & 120W52.10 & 1,027 & Teanaway \\
\hline VT2 & 46N58.04 & 119W58.95 & 1,270 & Vantage Two \\
\hline WA2 & $46 N 45.32$ & 119W33.94 & 244 & Wahluke Slope Two \\
\hline WAT & 47N41.92 & 119W57.24 & 821 & Waterville \\
\hline WIW & $46 N 25.76$ & 119W17.26 & 128 & Wooded Island \\
\hline WRD & $46 N 58.20$ & 119W08.69 & 375 & Warden \\
\hline YA2 & $46 N 31.60$ & 120W31.80 & 652 & Yakima Two \\
\hline YPT & 46N02.93 & 118W57.73 & 325 & Yellepit \\
\hline
\end{tabular}




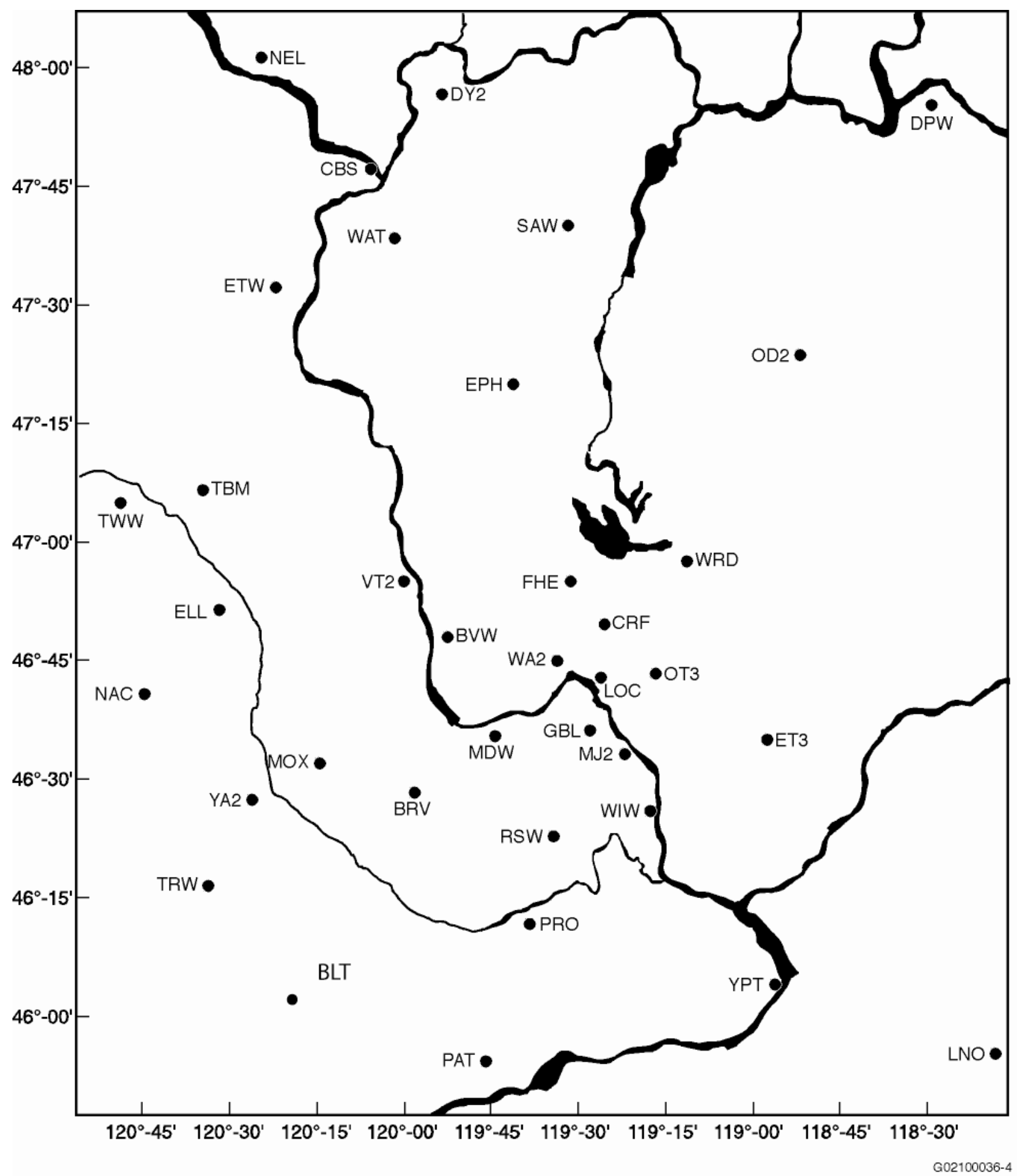

Figure 2.2. Locations of Seismograph Stations in the Eastern Washington Regional Network (see Table 2.2 for location descriptions) 


\subsubsection{Station Maintenance}

The HSN's maintenance records for the seismic sensor and relay sites are on file in the HSA office, Sigma V Building, Richland, Washington.

\subsubsection{Data Acquisition}

The signals from the seismometer sites are monitored for changes in signal amplitude that are expected from earthquakes. The seismic network is subdivided into spatial groupings of stations that are monitored for nearly simultaneous amplitude changes, resulting in triggering a permanent recording of the events. The groupings and associated weighting schemes are designed to allow very small seismic events to be recorded and to minimize false triggers. Events are classified as local (south-central Washington near the Hanford Site), regional (Western U.S. and Canada), and teleseisms (from farther distances around the world). Local and regional events are usually earthquakes, but quarry and mining explosions are also recorded. Quarry and mining explosions can usually be identified from wave characteristics, time of day, and through confirmation with local government agencies and industries. Frequently, military exercises at the U.S. Army's Yakima Training Center produce a series of acoustic shocks that unavoidably trigger the recording system. Sonic booms and thunder also produce acoustic signals that trigger the recording system.

A PC-based system (Earthworm system) adapted from a USGS program and the UW system was implemented at Hanford during FY 1999. One system has been in continuous operation since January 6, 1999. A second, backup PC system was installed in mid-March 1999, and both systems have been running in parallel since that time. The hardware and software have been periodically upgraded. Data from triggers are collected on a SUN ${ }^{\text {TM }}$ (registered trademark of Sun Microsystems, Santa Clara, California) workstation that is used to determine earthquake locations and magnitudes (Section 3). Although the two systems are practically identical, there is enough granularity (signal-to-noise) in the trigger timing that they sometimes record exclusive events. In nearly all cases, these exclusive triggers are "false" triggers, not earthquakes or quarry blasts (i.e., from acoustic sources). The remainders are from barely detectable, small signals from regional and teleseismic earthquakes.

\subsection{Strong Motion Accelerometer Sites}

\subsubsection{Location}

The Hanford SMA network consists of five free-field SMA sites (see Figure 2.1) (Table 2.3). There is one free-field SMA located in each of the 200 Separations Areas, one adjacent to the K Basins in the 100-K Area, one adjacent to the 400 Area where the Fast Flux Test Reactor is located, and one at the south end of the 300 Area. With the termination of the Fast Flux Test Reactor and draining of the liquid sodium coolant taking place now, plans have been made to terminate this site and move the instrument to a new location.

The instrumentation locations were chosen based on two criteria (Moore and Reidel 1996): 1) instruments should be located in areas having the highest densities of people and 2) instruments should be located in areas having hazardous facilities. Some of the highest concentrations of employees at Hanford are 200-East and West Areas, 100-K Area, the Fast Flux Test Facility (400 Area), and the 300 Areas. The 200 Areas are where high-level radioactive waste from past processing of fuel rods is stored in single- 
shell and double-shell tanks. In addition, the Canister Storage Facility that holds encapsulated spent fuel rods is in 200-East Area and the new Waste Treatment Plant, currently under construction, are also located in 200-East Area. The 100-K Area contains the K Basins where spent fuel rods from the N Reactor were stored prior to encapsulation. The Cold Vacuum Drying Facility, located in the 100-K Area, is used to encapsulate spent fuel rods from the K Basins prior to shipment to the Canister Storage Building in 200-East Area.

Table 2.3. Free-Field Strong Motion Accelerometer Sites

\begin{tabular}{||l|l|l|l||}
\hline \hline \multicolumn{1}{|c|}{ Site } & Site ID & \multicolumn{1}{c|}{$\begin{array}{c}\text { Latitude } \\
\text { Longitude } \\
\text { Elevation }\end{array}$} \\
\hline \hline 100-K Area & H1K & South of K Basins outside 100 Area fence lines. & $\begin{array}{l}46^{\circ} 38.51^{\prime} \\
119^{\circ} 35.53 \\
152 \mathrm{~m}\end{array}$ \\
\hline 200 East Area & H2E & $\begin{array}{l}\text { East of B Plant; north of 7th Street and east of } \\
\text { Baltimore Avenue. }\end{array}$ & $\begin{array}{l}46^{\circ} 33.58^{\prime} \\
119^{\circ} 32.00^{\prime} \\
210 \mathrm{~m}\end{array}$ \\
\hline 200 West Area & H2W & $\begin{array}{l}\text { West of Plutonium Finishing Plant (PFP) and 200-West } \\
\text { Area tree barrier. }\end{array}$ & $\begin{array}{l}46^{\circ} 33.11^{\prime} \\
119^{\circ} 38.64 \\
201 \mathrm{~m}\end{array}$ \\
\hline 300 Area & H3A & $\begin{array}{l}\text { South end of 300 Area inside fence lines (NE 1/4, } \\
\text { SW 1/4, Sec. 11, T10N, R28E). }\end{array}$ & $\begin{array}{l}46^{\circ} 21.83^{\prime} \\
119^{\circ} 16.55^{\prime} \\
119 \mathrm{~m}\end{array}$ \\
\hline
\end{tabular}




\subsubsection{Site Design}

All free-field SMA sites consist of a four-panel solar array and two 30-gallon galvanized drums. Each panel has a maximum 42-watt output. The two 30-gallon drums are set in the ground such that the base of the drum is about $1 \mathrm{~m}$ below the surface. One drum houses only the SMA; the other drum, which is connected via a sealed conduit to the SMA drum, contains the batteries. Communication is through a General Packet Radio Service (GPRS) system, which provides a continuous radio data-link with an internet service provider. This GPRS system along with the solar power regulator is housed in a small enclosure mounted at the rear of the solar array. The enclosure serves as a junction box for all cabling between equipment inside and outside of the drums through conduit. The antenna for the GPRS is mounted on top of the enclosure. The enclosure permits quick access to check battery conditions and a connection directly to the RS-232 port of the SMA without removing the drum lids.

The SMA instruments are three-component units consisting of one vertical, one north-south horizontal, and one east-west horizontal data channel. The instruments in use are the ETNA ${ }^{\mathrm{TM}}$ system (registered trademark of Kinemetrics, Inc., Pasadena, California). Instrument specifications are summarized in Table 2.4. In addition to the three-component SMAs, each ETNA SMA unit contains a computer, and a Global Positioning System (GPS) receiver (Figure 2.3). These systems are housed in a watertight box.

The GPRS system provides the internet address connection to access the system. Stations can be monitored from any computer with appropriate access. The data can be downloaded directly at each site via a built in cable connection at the enclosure in case of communication failure.

The SMAs have an internal GPS receiver used principally to link it to the National Bureau of Standards timing system. ${ }^{1}$ The GPS is internally activated approximately every 4 hours and checks the "location of the instrument" and the time. Any differences between the internal clock and the GPS time are recorded and saved by the SMA. Any corrections to the internal timing are made automatically. Typically, the greatest correction recorded is approximately 4 milliseconds.

\footnotetext{
${ }^{1}$ The GPS antenna is mounted on the enclosure at the rear of the solar array.
} 
Table 2.4. Instrument Parameters for the Kinemetrics ETNA ${ }^{\mathrm{TM}}$ System in the Hanford SMA Network

\begin{tabular}{||l|l||}
\hline \multicolumn{1}{||c||}{ Parameter } & \multicolumn{1}{|c||}{ Value or Range } \\
\hline \hline Sensor & Tri-Axial Force Balance Accelerometer orthogonally oriented with internal standard \\
\hline Type & $\pm 2 \mathrm{~g}^{(\mathrm{a})}$ \\
\hline Full-Scale & $0-50 \mathrm{~Hz}$ \\
\hline Frequency Range & Approximately 70\% critical ${ }^{(\mathrm{a})}$ \\
\hline Damping & 3 \\
\hline Data Acquisition & 18 -bit resolution @ 200 samples/second \\
\hline Number of Channels & Real-time, RS-232 Output Stream \\
\hline Sample Rate & $0.1-12.5$ Hz \\
\hline Digital Output & $0.1 \%{ }^{(\mathrm{b})}$ \\
\hline Seismic Trigger & Not activated \\
\hline Filter & 10 sec \\
\hline Trigger level & 40 sec \\
\hline Alarm (call-out) Threshold \\
\hline Pre-Event Memory & \begin{tabular}{|l||}
\hline Post-Event Time \\
(a) Setting is dependent on instrument calibration. \\
(b) See Section 2.2.4 for discussion of trigger thresholds.
\end{tabular} \\
\hline \hline
\end{tabular}

\section{Office of Seismic Assessment \\ Rm 2411, Sigma V Building \\ Richland, Washington}

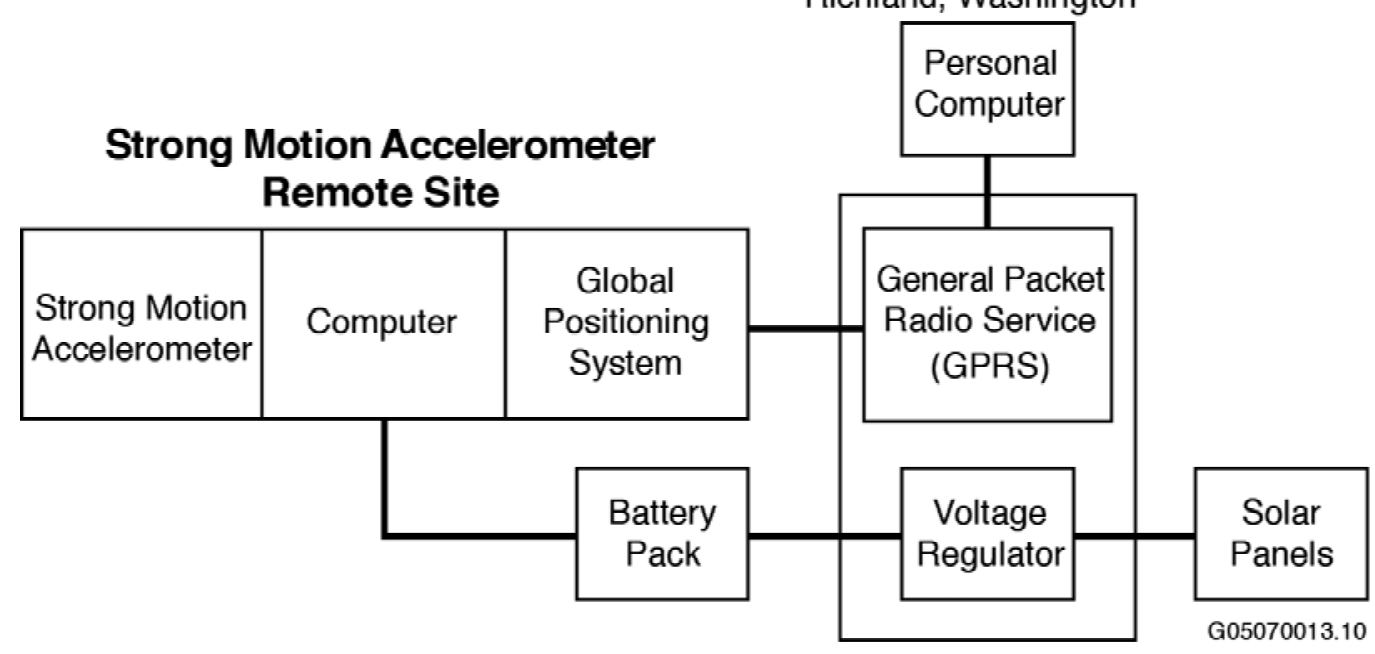

Figure 2.3. Schematic Diagram of a Strong Motion Accelerometer Installation

\subsubsection{Strong Motion Accelerometer Operations Center}

The combined operations, data recording, data interpretation, and maintenance facility is located in the Sigma V Building and is operated by the HSA.

\subsubsection{Strong Motion Operational Characteristics}

The signals from the three-accelerometer channels at each site are digitized with a 24-bit digitizer and temporarily stored in a memory buffer. The sampling rate of the digitizer is set to 200 samples/second. The three channels are monitored for signals that equal or exceed a programmable trigger threshold. 
When one accelerometer channel is triggered, the other channels automatically record. The nominal threshold used is $0.05 \%$ of the full-scale range of $2.0 \mathrm{~g}$ ( $\mathrm{g}$ is the acceleration of gravity, $9.8 \mathrm{~m} / \mathrm{s}^{2}$ or $32 \mathrm{ft} / \mathrm{s}^{2}$ ) or $0.001 \mathrm{~g}$. Threshold trigger levels are adjusted to trigger infrequently on the noise sources (e.g., vehicles, sonic booms) near each site. This provides ground motion data for smaller, non-damaging earthquakes that can be useful in estimating the ground motion expected from larger earthquakes, and to confirm correct operation of the instruments by analyzing the smaller-amplitude triggers. The recorders store information for 10 seconds before the trigger threshold is exceeded and for 40 seconds after the trigger ceases to be exceeded. 


\subsection{Earthquake Catalog Description}

The Hanford Seismic Assessment staff uses an interactive program XPED developed at the University of Washington to determine earthquake locations and magnitudes. This program operates on the sections of time saved in files by the trigger algorithm of the Earthworm system. It provides the user with the ability to measure the arrival times and durations of seismic waves from earthquakes and determine the locations and magnitudes of the events. Locations of teleseismic and regional earthquakes are interpreted and saved for operational and quality review and documentation, and are not reported here. Local earthquakes near the Hanford Site $\left(46^{\circ}-47^{\circ} \mathrm{N}\right.$ latitude, $119^{\circ}-120^{\circ} \mathrm{W}$ longitude) are reported in this report (Table 3.1). Other earthquakes in southeast Washington are kept on file.

\subsection{Coda Length Magnitude}

Coda-length magnitude $\left(\mathrm{M}_{\mathrm{c}}\right)$, an estimate of local magnitude $\left(\mathrm{M}_{\mathrm{L}}\right)$ (Richter 1958), is calculated using the coda-length/magnitude relationship determined for Washington State by Crosson (1972).

This relationship is:

$$
M_{c}=2.82 \log (D)-2.46 \text {, }
$$

where $\mathrm{D}$ is the duration of the observed signal.

\subsection{Velocity Model}

The program XPED uses the velocities and layer depths given in Table 3.2. This model does not include a surficial layer for the Hanford formation or Ringold Formation sediments because most stations are located on basalt. Time corrections, which account for elevation, or local differences in the velocity model (i.e., stations on sedimentary layers), are determined empirically from sets of accurately-located earthquakes and explosions in the region.

\subsection{Quality Factors (Q)}

XPED assigns a two-letter Quality factor (Table 3.1) that indicates the general reliability of the solution (A is best quality, $\mathbf{D}$ is worst). Similar quality factors are used by the USGS for events located with the computer program HYPO71. The first letter of the quality code is a measure of the hypocenter quality based primarily on travel time residuals. For example: Quality A requires a root-mean-square residual (RMS) less than 0.15 seconds while a $\mathbf{R M S}$ of 0.5 seconds or more is $\mathbf{D}$ quality (other estimates of the location uncertainty also affect this quality parameter). The second letter of the quality code is related to the spatial distribution of stations that contribute to the event's location, including the number of stations (NS), the number of p-wave and s-wave phases (NP), the largest gap in event-station azimuth distribution (GAP), and the closest distance from the epicenter to a station (DMIN). Quality A requires a solution with $\mathbf{N P}>8$, GAP $<90^{\circ}$, and DMIN $<5 \mathrm{~km}$ (or the hypocenter depth if it is greater than $5 \mathrm{~km}$ ). If $\mathbf{N P} \leq 5$, GAP $>180^{\circ}$, or $\mathbf{D M I N}>50 \mathrm{~km}$, the solution is assigned Quality $\mathbf{D}$. 
Table 3.1. Local Seismic Data, October 1, 2005 to December 31, 2005

\begin{tabular}{|c|c|c|c|c|c|c|c|c|c|c|c|c|}
\hline Event ID & Type & Date & Time & Latitude & Longitude & Depth & Mag & NS/NP & Gap & Dmin & RMS & Q \\
\hline 05100219330 & & 2005/10/02 & 19:32:94.57 & 46N29.10 & 119W21.61 & 6.15 & 1.2 & $14 / 017$ & 112 & 80.10 & 0.7 & $A B$ \\
\hline 05100603261 & & 2005/10/06 & 03:26:39.65 & 46N29.08 & 119W21.29 & 5.32 & 1.2 & $10 / 013$ & 142 & 80.11 & 1.2 & $\mathrm{AC}$ \\
\hline 05101113302 & & 2005/10/11 & 13:30:44.19 & 46N34.58 & 119W47.39 & 0.44 & -0.2 & 7/012 & 203 & 40.17 & 0.5 & $\mathrm{BD}$ \\
\hline 05101117422 & & 2005/10/11 & $17: 42: 51.34$ & 46N33.27 & 119W54.60 & 6.15 & -0.2 & $5 / 007$ & 196 & 130.30 & 3.8 & CD \\
\hline 05101119433 & & 2005/10/11 & 19:43:58.31 & 46N34.79 & 119W48.40 & 4.09 & -0.2 & 7/011 & 205 & 50.14 & 1.4 & $\mathrm{AD}$ \\
\hline 05101119484 & & 2005/10/11 & 19:48:64.42 & 46N34.87 & 119W46.35 & $0.03 *$ & -0.3 & $4 / 008$ & 193 & 30.20 & 0.1 & $\mathrm{BD}$ \\
\hline 05101203550 & & 2005/10/12 & 03:55:31.02 & 46N37.30 & 119W45.42 & 14.18 & -0.3 & $5 / 006$ & 261 & 10.04 & 0.4 & $\mathrm{AD}$ \\
\hline 05101209092 & & 2005/10/12 & 09:09:50.61 & 46N33.39 & 119W44.32 & 10.09 & -0.7 & 6/008 & 186 & 40.05 & 0.5 & $\mathrm{AD}$ \\
\hline 05101504470 & & 2005/10/15 & 04:46:87.52 & 46N42.77 & 119W30.03 & 1.06 & -0.2 & 8/011 & 81 & 50.09 & 2.5 & $\mathrm{BB}$ \\
\hline 05101615291 & & 2005/10/16 & 15:29:40.09 & 46N34.65 & 119W48.58 & $0.04 *$ & 0.3 & 9/013 & 207 & 50.10 & 0.1 & $\mathrm{AD}$ \\
\hline 05102021330 & $\mathrm{P}$ & $2005 / 10 / 20$ & 21:32:91.62 & 46N11.39 & 119W13.75 & $0.03 *$ & & $20 / 020$ & 146 & 200.17 & 0.7 & $\mathrm{BC}$ \\
\hline 05102917081 & & 2005/10/29 & 17:08:30.08 & 46N41.57 & 119W39.82 & 7.90 & -0.9 & 6/007 & 187 & 90.07 & 0.4 & $\mathrm{AD}$ \\
\hline 05111012453 & & 2005/11/10 & $12: 45: 59.25$ & 46N08.30 & 119W55.75 & 11.45 & 2.6 & $34 / 037$ & 71 & 200.18 & 0.9 & $\mathrm{BB}$ \\
\hline 05111013052 & & $2005 / 11 / 10$ & 13:05:47.57 & 46N08.95 & 119W55.60 & $8.27 *$ & 1.2 & $14 / 014$ & 113 & 190.06 & 0.3 & $\mathrm{AC}$ \\
\hline 05111118533 & $\mathrm{P}$ & 2005/11/11 & 18:53:58.39 & 46N25.87 & 119W01.45 & $0.02 *$ & & 9/009 & 151 & 170.28 & 0.3 & $\mathrm{BC}$ \\
\hline 05112119580 & $\mathrm{P}$ & $2005 / 11 / 21$ & 19:57:85.21 & 46N14.97 & 119W43.12 & $0.03 *$ & & 9/009 & 212 & 40.19 & 1.0 & $\mathrm{BD}$ \\
\hline 05120107082 & & 2005/12/01 & 07:08:44.33 & 46N43.30 & 119W30.34 & 3.23 & -0.7 & 7/011 & 89 & 50.11 & 1.0 & $\mathrm{AB}$ \\
\hline 05120113050 & & 2005/12/01 & 13:04:84.79 & 46N42.91 & 119W29.27 & 5.33 & -0.9 & 3/005 & 225 & 40.04 & 0.5 & $\mathrm{AD}$ \\
\hline 05120305012 & & 2005/12/03 & 05:01:53.03 & 46N43.02 & 119W29.82 & $0.02 *$ & 0.5 & 8/009 & 77 & 50.10 & 0.0 & $\mathrm{AB}$ \\
\hline 05120314524 & & 2005/12/03 & 14:52:73.27 & 46N43.19 & 119W29.95 & 3.61 & 0.4 & $12 / 015$ & 68 & 50.12 & 0.7 & $\mathrm{AB}$ \\
\hline 05120314552 & & 2005/12/03 & $14: 55: 44.73$ & $46 \mathrm{~N} 43.23$ & 119W30.13 & 5.99 & -0.1 & 8/009 & 88 & 50.11 & 0.9 & AA \\
\hline 05120319365 & & 2005/12/03 & 19:36:76.35 & 46N43.17 & 119W30.02 & 4.39 & -0.6 & 7/009 & 87 & 50.09 & 0.9 & $\mathrm{AB}$ \\
\hline 05120323505 & & 2005/12/03 & 23:50:80.94 & 46N43.53 & 119W29.88 & 1.71 & -0.1 & 6/007 & 157 & 50.04 & 1.3 & $\mathrm{AC}$ \\
\hline 05120404095 & & $2005 / 12 / 04$ & 04:09:76.06 & 46N43.52 & 119W30.04 & 4.83 & 0.5 & $10 / 010$ & 99 & 50.12 & 1.1 & $\mathrm{AB}$ \\
\hline
\end{tabular}


Table 3.1. (cont'd)

\begin{tabular}{|c|c|c|c|c|c|c|c|c|c|c|c|c|}
\hline Event ID & Type & Date & Time & Latitude & Longitude & Depth & Mag & NS/NP & Gap & Dmin & RMS & Q \\
\hline 05120404482 & & $2005 / 12 / 04$ & :48:43.57 & $46 N 43.49$ & 119W30.34 & 5.08 & -0.2 & 7/009 & 92 & 50.09 & 1.0 & $A B$ \\
\hline 05120404551 & & $2005 / 12 / 04$ & 04:55:45.57 & 46N43.12 & 119W30.10 & $0.05 *$ & 1.2 & $16 / 017$ & 70 & 0.09 & 0.1 & $\mathrm{AB}$ \\
\hline 05120404591 & & $2005 / 12 / 04$ & 04:59:35.13 & 46N43.31 & 119W30.29 & 5.05 & 0.4 & $11 / 014$ & 70 & 50.13 & 1.1 & $\mathrm{AB}$ \\
\hline 05120405004 & & 2005/12/04 & 04:59:22.68 & $46 \mathrm{~N} 43.27$ & 119W29.90 & $0.04 *$ & 1.5 & $20 / 022$ & 66 & 50.11 & 0.0 & $\mathrm{AB}$ \\
\hline 05120405013 & & 2005/12/04 & 04:59:53.08 & 46N43.59 & 119W30.07 & 0.46 & -0.3 & $5 / 007$ & 95 & 50.15 & 0.6 & $\mathrm{AD}$ \\
\hline 05120405232 & & $2005 / 12 / 04$ & 05:23:50.22 & $46 \mathrm{~N} 43.20$ & $119 \mathrm{~W}$ & 3.00 & 0.0 & 8/010 & 87 & 0.12 & 1.6 & $A B$ \\
\hline 05120 & & $2005 / 12 / 04$ & $05: 51$ & $46 \mathrm{~N}$ & $119 \mathrm{r}$ & 5.76 & -0.8 & 7/007 & 91 & 5 & 1.7 & $\mathrm{AB}$ \\
\hline 051204 & & $2005 / 12 / 04$ & 07:20:78.99 & $46 \mathrm{~N} 4$ & $119 \mathrm{n}$ & 4.41 & -0.4 & 7/008 & 87 & 2 & 1 & $\mathrm{AB}$ \\
\hline 05120409360 & & $2005 / 12 / 04$ & 09:36:29.47 & $46 N 44.16$ & $119 \mathrm{~W}$ & 4.14 & -0.7 & 6/010 & 178 & 4 & 1.3 & AC \\
\hline 05120417210 & & $2005 / 12 / 04$ & $17: 20: 80.51$ & $46 \mathrm{~N} 18.25$ & 119W31.51 & 17.08 & -0.3 & 9/013 & 233 & 60.06 & 0.5 & $\mathrm{AD}$ \\
\hline 05120521125 & $\mathrm{P}$ & $2005 / 12 / 05$ & 21:12:76.57 & 46N16.30 & $119 W 23.10$ & $0.02 *$ & & $12 / 012$ & 127 & 40.09 & 0.2 & $\mathrm{AB}$ \\
\hline 05120709163 & & 2005/12/07 & 09:16:53.97 & $46 N 43.04$ & $119 W 29.63$ & 1.93 & -0.3 & 8/011 & 86 & 40.13 & 1.5 & AA \\
\hline 05120709552 & & 2005/12/07 & 09:55:52.26 & $46 N 42.94$ & 119W29.57 & 2.48 & -0.4 & 7/009 & 85 & 40.10 & 1.1 & $\mathrm{AB}$ \\
\hline 05120819204 & & $2005 / 12 / 08$ & 19:20:69.88 & $46 N 43.46$ & 119W30.12 & 4.04 & -0.2 & 7/010 & 92 & 50.12 & 1.0 & $\mathrm{AB}$ \\
\hline 05120902400 & & 2005/12/09 & 02:39:84.19 & $46 N 43.62$ & 119W30.73 & 2.36 & -0.2 & 8/009 & 152 & 50.16 & 3.3 & $\mathrm{BC}$ \\
\hline 05120905403 & & 2005/12/09 & $05: 40: 55.58$ & $46 N 43.44$ & 119W30.46 & $0.04 *$ & -0.4 & 7/009 & 91 & 50.15 & 0.1 & $\mathrm{AB}$ \\
\hline 05120911150 & & 2005/12/09 & 11:14:89.95 & $46 N 43.33$ & 119W30.18 & 4.60 & 0.3 & 9/012 & 95 & 50.11 & 0.9 & $\mathrm{AB}$ \\
\hline 05120923194 & & 2005/12/09 & 23:19:67.25 & $46 N 43.75$ & 119W30.88 & 6.08 & -0.6 & $5 / 009$ & 95 & 40.14 & 1.6 & $\mathrm{AD}$ \\
\hline 05 & & 10 & 87 & $46 \Gamma$ & 1 & 4.00 & -0.2 & 7/008 & 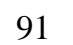 & 7 & 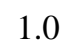 & $\mathrm{AB}$ \\
\hline 10 & & 10 & .57 & $46 \mathrm{~N}$ & .76 & $0.03 *$ & 0.6 & 4/015 & 68 & 13 & 0.1 & $\overline{A A}$ \\
\hline 05121015262 & & 10 & .76 & 17 & 9 & 3.37 & 0.7 & $11 / 012$ & 88 & 13 & 1.3 & AA \\
\hline 290 & & $2 / 10$ & $15: 28: 85.29$ & $46 N 43.67$ & 0.69 & 6.46 & -0.5 & /007 & 94 & 0.09 & 1.3 & $A B$ \\
\hline 594 & & $2005 / 12 / 10$ & 15:59:67.09 & $46 N 43.25$ & 119W30.64 & 4.45 & -0.3 & 9/011 & 86 & 50.10 & 1.0 & $\mathrm{AB}$ \\
\hline 05121515190 & & $2005 / 12 / 15$ & 15:18:88.90 & $46 N 42.93$ & 119W29.77 & 3.24 & 0.1 & $10 / 013$ & 84 & 50.07 & 0.5 & $\mathrm{AB}$ \\
\hline
\end{tabular}


Table 3.1. (cont'd)

\begin{tabular}{||c|c|c|c|c|c|r|c|c|c|c|c|c||}
\hline Event ID & Type & Date & Time & Latitude & Longitude & Depth & Mag & NS/NP & Gap & Dmin & RMS & Q \\
\hline \hline 05121705165 & & $2005 / 12 / 17$ & $05: 16: 74.52$ & $46 N 29.19$ & $119 W 21.27$ & 5.91 & -0.5 & $6 / 009$ & 174 & 80.05 & 0.4 & AC \\
\hline 05121708131 & & $2005 / 12 / 17$ & $08: 13: 37.47$ & $46 N 42.85$ & $119 W 30.12$ & 2.11 & 0.3 & $10 / 013$ & 93 & 50.12 & 1.6 & AB \\
\hline 05121802155 & & $2005 / 12 / 18$ & $02: 15: 78.01$ & $46 N 43.51$ & $119 W 30.79$ & 6.20 & -0.8 & $6 / 007$ & 95 & 50.12 & 1.7 & AC \\
\hline 05121803540 & & $2005 / 12 / 18$ & $03: 54: 26.31$ & $46 N 43.01$ & $119 W 30.30$ & 3.57 & 0.0 & $7 / 009$ & 84 & 50.05 & 0.3 & AB \\
\hline 05121902281 & & $2005 / 12 / 19$ & $02: 28: 41.12$ & $46 N 34.49$ & $119 W 41.39$ & 7.74 & -1.1 & $4 / 006$ & 109 & 60.03 & 1.0 & AD \\
\hline 05121903221 & & $2005 / 12 / 19$ & $03: 22: 44.02$ & $46 N 34.16$ & $119 W 41.44$ & 7.99 & -0.8 & $3 / 006$ & 152 & 50.02 & 0.2 & AD \\
\hline 05122009324 & & $2005 / 12 / 20$ & $09: 32: 65.53$ & $46 N 43.11$ & $119 W 30.09$ & 3.03 & -0.2 & $8 / 012$ & 86 & 50.11 & 0.9 & AB \\
\hline 05122312412 & & $2005 / 12 / 23$ & $12: 41: 52.87$ & $46 N 26.47$ & $119 W 35.57$ & 16.48 & -0.3 & $9 / 011$ & 117 & 50.06 & 0.8 & AB \\
\hline 05122800143 & & $2005 / 12 / 28$ & $00: 14: 61.17$ & $46 N 29.12$ & $119 W 21.16$ & 0.14 & -0.4 & $5 / 007$ & 144 & 70.16 & 1.5 & BD \\
\hline 05122807352 & & $2005 / 12 / 28$ & $07: 35: 43.28$ & $46 N 43.50$ & $119 W 30.45$ & 3.42 & -0.4 & $6 / 010$ & 151 & 50.17 & 2.3 & BC \\
\hline 05122810593 & & $2005 / 12 / 28$ & $10: 59: 57.45$ & $46 N 43.36$ & $119 W 30.02$ & 4.06 & 0.6 & $9 / 013$ & 70 & 50.07 & 0.5 & AB \\
\hline 05122910293 & & $2005 / 12 / 29$ & $10: 29: 60.92$ & $46 N 28.78$ & $119 W 22.29$ & 4.21 & 1.0 & $11 / 015$ & 104 & 80.11 & 1.4 & AB \\
\hline 05123012341 & & $2005 / 12 / 30$ & $12: 34: 40.46$ & $46 N 43.19$ & $119 W 30.07$ & 3.14 & -0.3 & $6 / 007$ & 90 & 50.11 & 2.0 & AC \\
\hline \hline
\end{tabular}




\section{Explanation of Table 3.1}

Event ID: The Earthworm Recording System creates the identification number. XPED uses the year, month, day, and time to create a unique number for each event.

Type: $\quad$ P is Probable Blast; $\mathrm{X}$ is Confirmed Blast; F is Felt Earthquake; blank is local earthquake.

Date: The year and day of the year in Universal Time Coordinated (UTC). UTC is used throughout this report unless otherwise indicated.

Time: $\quad$ The origin time of the earthquake given in UTC. To covert UTC to Pacific Standard Time, subtract eight hours; to Pacific Daylight Time, subtract seven hours.

Latitude: North latitude, in degrees and minutes, of the earthquake epicenter.

Longitude: West longitude, in degrees and minutes, of the earthquake epicenter.

Depth: $\quad$ The depth of the earthquake in kilometers $(\mathrm{km})$.

Mag: $\quad$ The magnitude is expressed as Coda-Length magnitude $\mathbf{M}_{c}$, an estimate of local magnitude $\mathrm{M}_{\mathrm{L}}$ (Richter 1958). If magnitude is blank, a determination was not made.

NS/NP: $\quad$ Number of stations/number of phases used in the solutions.

Gap: Azimuthal gap. The largest angle (relative to the epicenter) containing no stations.

DMIN: $\quad$ The distance from the earthquake epicenter to the closest station.

RMS: $\quad$ The root-mean-square residual (observed arrival times minus the predicted arrival times) at all stations used to locate the earthquake. It is only useful as a measure of quality of the solution when five or more well-distributed stations are used in the solution. Good solutions are normally characterized by RMS values of less than about 0.3 seconds.

Q: $\quad$ The Quality Factors indicate the general reliability of the solution/location (A is best quality, D is worst). See Section 3.3 of this report, "Quality Factors." 
Table 3.2. Seismic Velocities for Columbia Basin Stratigraphy (from Rohay et al. 1985)

\begin{tabular}{||c|l|c||}
\hline $\begin{array}{c}\text { Depth to Top of Velocity } \\
\text { Layer }(\mathrm{km})\end{array}$ & \multicolumn{1}{|c|}{ Stratigraphy } & $\begin{array}{c}\text { Velocity } \\
(\mathrm{km} / \mathrm{sec})\end{array}$ \\
\hline \hline 0.0 & $\begin{array}{l}\text { Saddle Mountains and Wanapum Basalts and intercalated } \\
\text { Ellensburg Formation }\end{array}$ & 3.7 \\
\hline 0.4 & Grande Ronde Basalt and pre-basalt sediments & 5.2 \\
\hline 8.5 & Crystalline Basement, Layer 1 & 6.1 \\
\hline 13.0 & Crystalline Basement, Layer 2 & 6.4 \\
\hline 23.0 & Sub-basement & 7.1 \\
\hline 38.0 & Mantle & 7.9 \\
\hline
\end{tabular}




\subsection{Geology and Tectonic Analysis}

The Hanford Site lies within the Columbia Basin, which is an intermontane basin between the Cascade Range and the Rocky Mountains that is filled with Cenozoic volcanic rocks and sediments. This basin forms the northern part of the Columbia Plateau physiographic province (Fenneman 1931) and the Columbia River flood-basalt province (Reidel and Hooper 1989). In the central and western parts of the Columbia Basin, the Columbia River Basalt Group (CRBG) overlies Tertiary continental sedimentary rocks and is overlain by late Tertiary and Quaternary fluvial and glaciofluvial deposits (Campbell 1989; Reidel et al. 1989, 1994; DOE 1988). In the eastern part, a thin ( $<100 \mathrm{~m})$ sedimentary unit separates the basalt and underling crystalline basement and a thin $(<10 \mathrm{~m})$ veneer of eolian sediments overlies the basalt (Reidel et al. 1989, 1994).

The Columbia Basin has two structural subdivisions or subprovinces: the Yakima Fold Belt and the Palouse Slope. The Yakima Fold Belt includes the western and central parts of the Columbia Basin and is a series of anticlinal ridges and synclinal valleys with major thrust faults along the northern flanks (Figure 4.1) (Reidel and Fecht 1994a, 1994b). The Palouse Slope is the eastern part of the basin and is less deformed than the Yakima Fold Belt with only a few faults and low amplitude, long wavelength folds on an otherwise gently westward dipping paleoslope. Figure 4.2 shows north-south (B-B') and east-west (A-A') cross sections through the Columbia Basin based on surface mapping (Reidel and Fecht 1994a, 1994b), deep boreholes (Reidel et al. 1994), geophysical data (Rohay et al. 1985; DOE 1988), and magnetotelluric data obtained as part of BWIP (DOE 1988).

\subsection{Earthquake Stratigraphy}

Studies of seismicity at the Hanford Site have shown that the seismic activity is related to crustal stratigraphy (layers of rock types) (Rohay et al. 1985; DOE 1988). The main geologic units important to earthquakes at the Hanford Site and the surrounding area are:

- The Miocene Columbia River Basalt Group (CRBG)

- Pre-basalt sediments of Paleocene, Eocene, Oligocene, and Early Miocene age

- The crystalline basement consisting of two layers composed of Precambrian and Paleozoic craton

- Mesozoic accreted terranes.

\subsection{Geologic Structure Beneath the Monitored Area}

Between the late 1950s and the mid 1980s, deep boreholes were drilled for hydrocarbon exploration in the Columbia Basin. These boreholes provided accurate measurements of the physical properties of the CRBG and the pre-basalt sediments (Reidel et al. 1989, 1994), but the thickness of the pre-basalt sediments and nature of the crystalline basement are still poorly understood. The difference between the thicknesses listed in Table 4.1 and the thicknesses of the crustal layers in the velocity model in Table 3.1 reflect data specific to UW's crustal velocity model for eastern Washington. Table 4.1 is derived from Reidel et al. (1994) and was developed for the geologic interpretation in this report. The thicknesses of these units are variable across the monitored area. Table 4.1 summarizes the approximate thickness at the borders of the monitored area. 


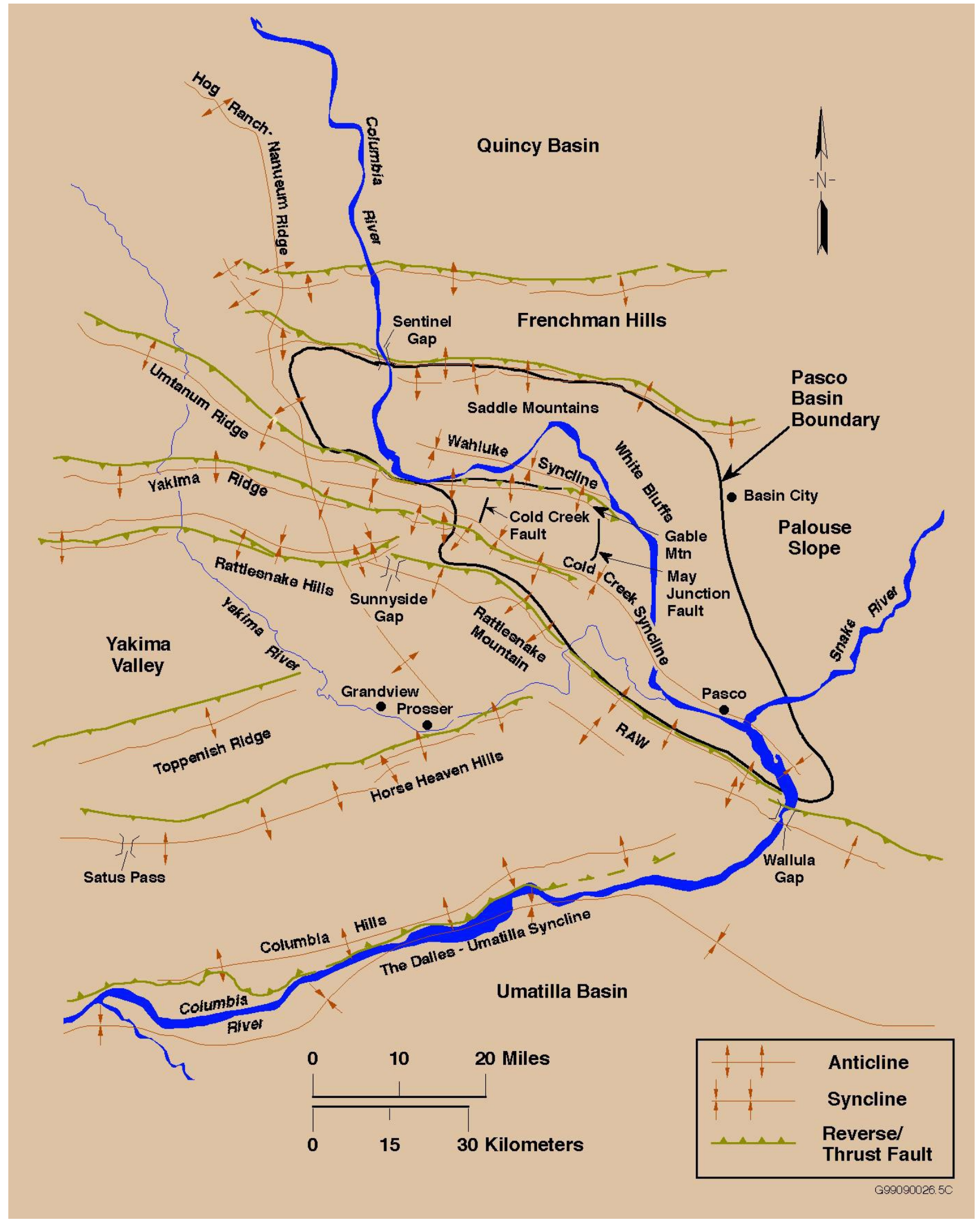

Figure 4.1. Tectonic Map of Columbia Basin Showing Major Seismic Source Structures 


\section{Yakima Fold Belt}

Palouse Slope
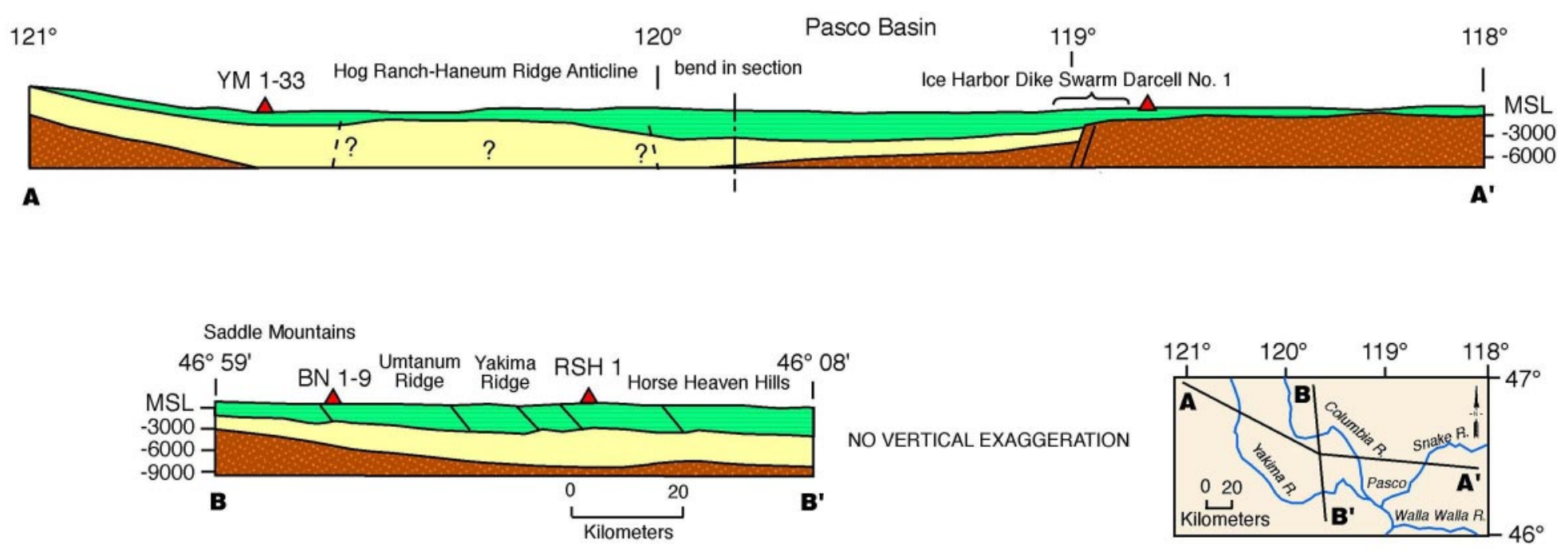

$\Delta$ Hydrocarbon exploration borehole

Columbia River Basalt Group

Tertiary sediments

Basement rock

G01010082.2

Figure 4.2. Geologic Cross Sections Through the Columbia Basin (Reidel et al. 1994) 
Table 4.1. Thicknesses of Stratigraphic Units in the Monitoring Area (from Reidel et al. 1994)

\begin{tabular}{||l|c|c|c|c||}
\hline \multicolumn{1}{|c|}{ Stratigraphy } & North & South & East & West \\
\hline \hline Columbia River Basalt Group (includes suprabasalt sediments) & $3.0 \mathrm{~km}$ & $4.5 \mathrm{~km}$ & $2.2 \mathrm{~km}$ & $4.2 \mathrm{~km}$ \\
\hline Pre-Basalt Sediments & $3.0 \mathrm{~km}$ & $>4.5 \mathrm{~km}$ & 0 & $>6.0 \mathrm{~km}$ \\
\hline
\end{tabular}

The thickness of the basalt and the pre-basalt sediments varies as a result of different tectonic environments. The western edge of the North American craton (late Precambrian/Paleozoic continental margin and Precambrian craton) is located east of the Pasco Basin. The stratigraphy on the craton consists of CRBG overlying crystalline basement; the crystalline basement is continental crustal rock that underlies much of the western North America. The stratigraphy west of the craton consists of two parts. The exact western edge of the North American craton in Washington is not known. Between the Pasco Basin and the craton, there is about 4 to $5 \mathrm{~km}$ of CRBG overlying a thin section of early Cenozoic sediments. This early Cenozoic sediment lies on rocks of accreted terranes of Mesozoic age. Directly underlying the Pasco Basin is 4 to $5 \mathrm{~km}$ of CRBG overlying at least $6 \mathrm{~km}$ of pre-basalt sediments. This in turn overlies what is assumed to be accreted terranes. The area underlying the Pasco Basin was subsiding during the Eocene and Oligocene, accumulating great thickness of pre-CRBG sediments. Continued subsidence in this area during the Miocene resulted in thicker CRBG compared to that on the craton. Subsidence continues today but at a greatly reduced rate (Reidel et al. 1994).

\subsection{Tectonic Pattern}

Studies have concluded that earthquakes can occur in the following six different tectonic environments (earthquake sources) at the Hanford Site (Geomatrix 1996).

- Major Geologic Structures. Reverse/thrust faults in the CRBG associated with major anticlinal ridges such as Rattlesnake Mountain, Yakima Ridge, and Umtanum Ridge could produce some of the largest earthquakes.

- Secondary faults. These faults are typically smaller (1 to $20 \mathrm{~km}$ ) than the main reverse/thrust faults that occur along the major anticlinal ridges (up to $100 \mathrm{~km}$ ). Secondary faults can be segment boundaries (tear faults) and small faults of any orientation that formed along with the main structure.

- Swarm areas. Small geographic areas not known to contain any geologic structures produce clusters of events (swarms), usually in the CRBG in synclinal valleys. These clusters consist of a series of small shocks with no outstanding principal event. Swarms occur over a period of days or months and the events may number into the hundreds and then quit, only to start again at a later date. This differs from the sequence of foreshocks, mainshock, and trailing-off aftershocks that have the same epicenter or are associated with the same fault system. In the past, swarms were thought to occur only in the CRBG. Most swarm areas are in the basalt but swarm events also appear to occur in all geologic layers. However, typically a swarm event at a specific time is usually restricted to one layer. There are seven earthquake swarm areas that are recognized in the Hanford Seismic Network area but this list will be updated as new swarm areas develop. The Saddle Mountains swarm area, Wooded Island swarm area, Wahluke swarm area, Coyote Rapids swarm area, and Horse Heaven Hills swarm area are typically active at one time or another during the year. The other earthquake swarm areas are active less frequently. 
- The entire Columbia Basin. The entire basin, including the Hanford Site, could produce a "floating" earthquake. A floating earthquake is one that, for seismic design purposes, can happen anywhere in a tectonic province and is not associated with any known geologic structure. Seismic interpretation classifies it as a random event for purposes of seismic design and vibratory ground motion studies.

- Basement source structures. Studies (Geomatrix 1996) suggest that major earthquakes can originate in tectonic structures in the crystalline basement. Because little is known about geologic structures in the crystalline basement beneath the Hanford Site, earthquakes cannot be directly tied to a mapped fault. Earthquakes occurring in the crystalline basement without known sources are treated as random events.

- The Cascadia Subduction Zone. This source has been postulated to be capable of producing a magnitude 9 earthquake. Because this source is along the western boundary of Washington State and outside the HSN, the Cascadia Subduction Zone is not an earthquake source that is monitored at the Hanford Site, so subduction zone earthquakes are not reported here. Because any earthquake along the Cascadia Subduction zone can have a significant impact on the Hanford Site, or can be felt like the February 2001 Nisqually earthquake, UW monitors and reports on this earthquake source for the DOE. Ground motion from any moderate or larger Cascadia Subduction Zone earthquake is detected by Hanford SMAs and reported (see Section 5.0).

\subsection{Depth of Earthquakes}

Since records have been kept, most of the earthquakes at the Hanford Site have originated in the CRBG layer. The crystalline basement has had the next greatest amount of earthquakes followed by the pre-basalt sediments. The stratigraphic units for local earthquakes recorded during the first quarter of FY 2006 are listed in Table 4.2.

Table 4.2. Number of Local Earthquakes Occurring in Stratigraphic Units

\begin{tabular}{||l|c|c|c|c|c||}
\hline \multicolumn{1}{|c|}{ Unit } & First Quarter & Second Quarter & Third Quarter & Fourth Quarter & FY 2005 \\
\hline \hline Basalt & 46 & - & - & - & 46 \\
\hline Pre-Basalt Sediments & 6 & - & - & - & 6 \\
\hline Crystalline Basement & 5 & - & - & - & 5 \\
\hline Total & 57 & - & - & - & 57 \\
\hline \hline
\end{tabular}

\subsection{Tectonic Activity}

\subsubsection{Summary}

During the first quarter of FY 2006, there were 57 earthquakes that occurred within the Hanford Seismic Monitoring Network (Table 4.3; Figure 4.3). Forty six (81\%) events occurred in the CRBG; six (10\%) occurred in the pre-basalt sediments; and 5 (9\%) events occurred in the crystalline basement. No events are interpreted as occurring along major geologic structures; 50 (88\%) events are interpreted as occurring in earthquake swarms; and seven (12\%) events are interpreted as random events. 
Table 4.3. Summary of Earthquake Locations for FY 2005

\begin{tabular}{|c|c|c|c|c|c|c|}
\hline \multicolumn{2}{|c|}{ Seismic Sources } & $\begin{array}{l}\text { First Quarter } \\
10 / 01-12 / 31\end{array}$ & $\begin{array}{c}\text { Second Quarter } \\
1 / 01-3 / 31\end{array}$ & $\begin{array}{c}\text { Third Quarter } \\
\text { 4/01 - 6/30 }\end{array}$ & $\begin{array}{c}\text { Fourth Quarter } \\
7 / 01-9 / 30\end{array}$ & FY 2005 \\
\hline \multicolumn{2}{|c|}{ Geologic Structure } & - & - & - & - & - \\
\hline \multirow{10}{*}{ Swarm } & Frenchman Hills & - & - & - & - & - \\
\hline & $\begin{array}{l}\text { Saddle Mountains/ } \\
\text { Royal Slope }\end{array}$ & - & - & - & - & - \\
\hline & Wahluke Slope & 1 & - & - & - & 1 \\
\hline & Coyote Rapids & 39 & - & - & - & 39 \\
\hline & Wye & 4 & - & - & - & 4 \\
\hline & Wooded Island & - & - & - & - & - \\
\hline & Cold Creek & 6 & - & - & - & 6 \\
\hline & Rattlesnake Mt. & - & - & - & - & - \\
\hline & $\begin{array}{l}\text { Horse Heaven } \\
\text { Hills }\end{array}$ & - & - & - & - & - \\
\hline & $\begin{array}{l}\text { Total for swarm } \\
\text { areas }\end{array}$ & 50 & - & - & - & 50 \\
\hline \multicolumn{2}{|c|}{ Random Events } & 7 & - & - & - & 7 \\
\hline \multicolumn{2}{|c|}{ Total for all earthquakes } & 57 & - & - & - & 57 \\
\hline
\end{tabular}

\subsubsection{First Quarter Earthquakes of FY 2006}

Fifty seven earthquakes occurred in the Hanford area during the first quarter of FY 2006 (October 1, 2005 through December 31, 2005 [Figure 4.3]) (Table 4.3).

\subsubsection{Location and Depth of Earthquakes}

\subsection{Major Anticlinal Ridges}

During the first quarter of FY 2006, we interpret no seismic events to have occurred on major geologic structures.

\subsection{Earthquake Swarm Areas}

Fifty earthquakes were located in swarm events (Figure 4.3).

\section{Coyote Rapids Swarm Area}

Thirty nine earthquakes occurred at the northeastern end of the Coyote Rapids swarm area starting on October 15, 2005 and continuing into 2006. All events were less than $1.0 \mathrm{M}_{\mathrm{c}}$ and all occurred in the basalt. The earthquakes were concentrated at the 'horn' of the Columbia River (inset Figure 4.3). Most of the earthquakes occurred in December (Figure 4.4). 


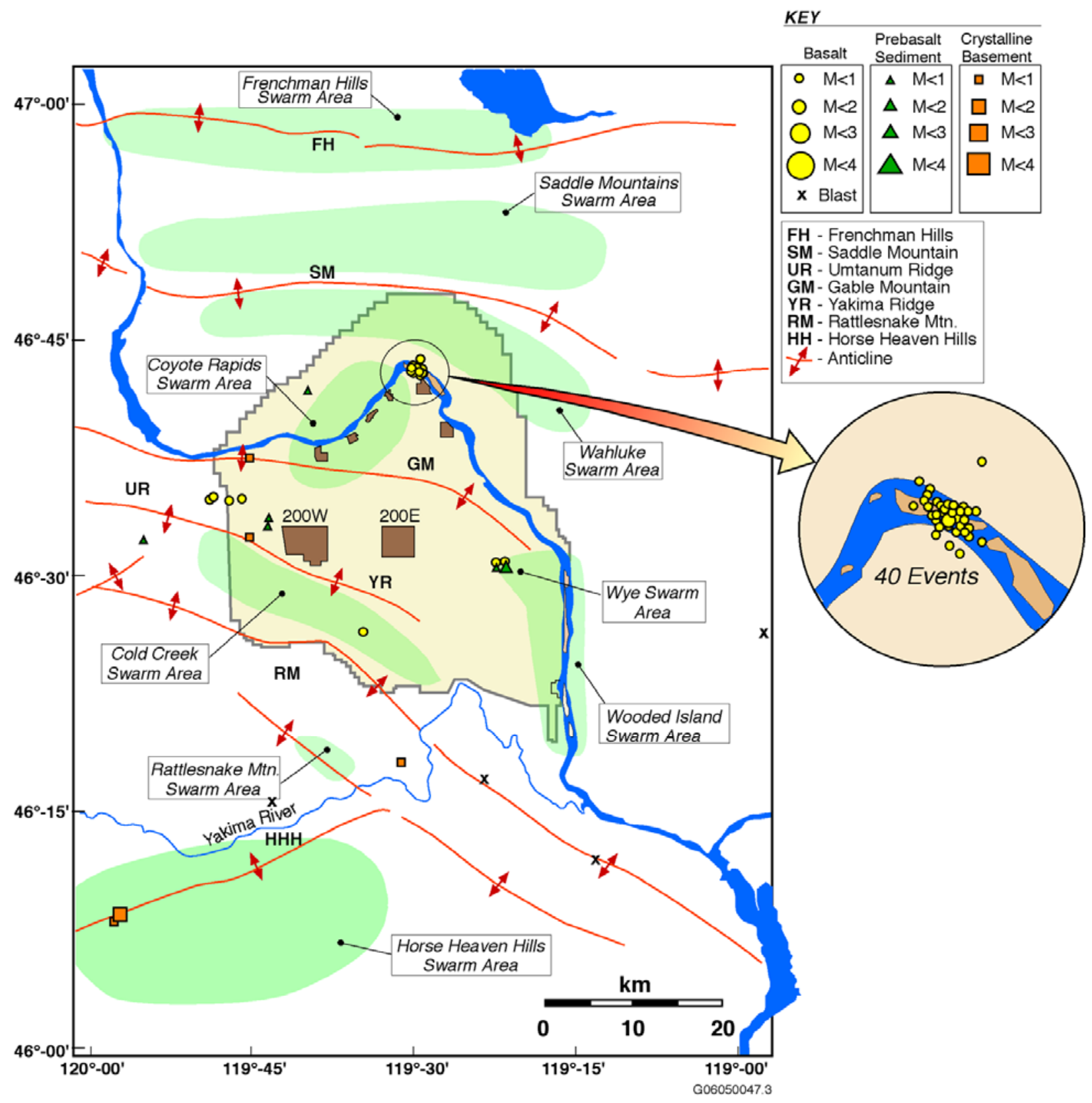

Figure 4.3. All Earthquakes Recorded Within the Hanford Monitoring Area during the First Quarter of FY 2006 (October 1, 2005-December 31, 2005). North is top of figure.

\section{Wahluke Swarm Area}

One small (approximately $0.0 \mathrm{M}_{\mathrm{c}}$ ) earthquake occurred in the Wahluke Swarm Area during the first quarter of FY 2006. This earthquake occurred on October 29 and was in the pre-basalt sediments. This event was west of the Coyote Rapids earthquake swarm. 


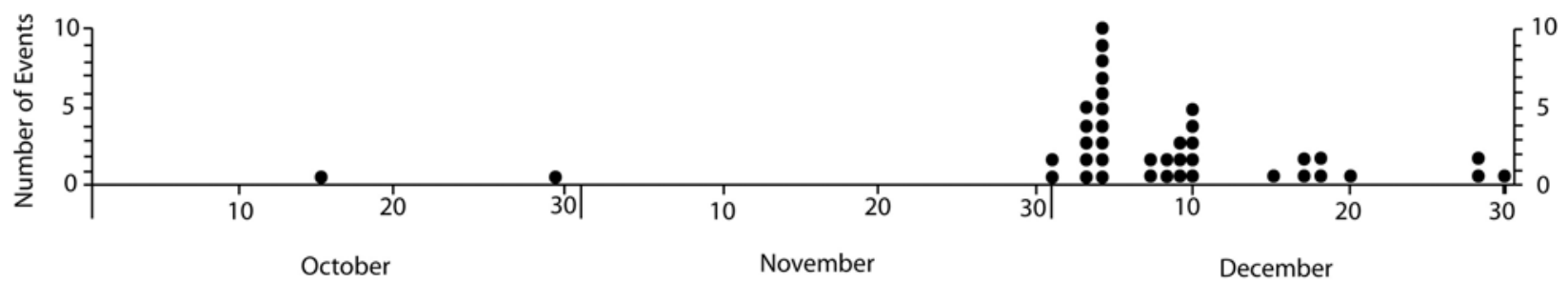

Figure 4.4. Timing of Earthquakes in the Coyote Rapids Earthquake Swarm during the First Quarter of FY 2006.

\section{Wye Swarm Area}

Four earthquakes occurred in the Wye Barricade Swarm Area during the first quarter of FY 2006. The first two occurred on October 2 and October 6 and had magnitudes of $1.2 \mathrm{M}_{\mathrm{c}}$. These two events occurred in the pre-basalt sediments. The next earthquake occurred on December 28. This event was small (approximately $0.0 \mathrm{M}_{\mathrm{c}}$ ) and occurred in the basalt. The final earthquake to occur in this swarm area during the first quarter was on December 29. It also occurred in the basalt and had a magnitude of $1.0 \mathrm{M}_{\mathrm{c}}$.

\section{Cold Creek Swarm Area}

Six earthquakes occurred in the western end of the Cold Creek Swarm Area during the first quarter of FY 2006. Four of the earthquakes occurred on October 11 and were in the basalt or near the base of the basalt. All four events were small (approximately $0.0 \mathrm{M}_{\mathrm{c}}$ ). The next earthquake to occur was on October 12. This event occurred in the crystalline basement and was small (approximately $0.0 \mathrm{M}_{\mathrm{c}}$ ). The last earthquake to occur in the swarm area during the first quarter was on October 16. This event occurred in the basalt and was small approximately $0.0 \mathrm{M}_{\mathrm{c}}$ ).

\subsection{Random or Floating Events}

During the first quarter of FY 2006, we interpret seven random events to have occurred in the monitoring area. Events that occurred in the pre-basalt sediments and in the crystalline basement are typically classified as random events. This is because there are no known geologic structures that have been identified in the rocks that occur below the Columbia River Basalt Group. However, we now recognize that some events that occur at depths that places them in the pre-basalt sediments and crystalline basement occur in patterns that fit our definition of earthquake swarms (Section 4.3). Those events are now reported in the appropriate sections on earthquake swarms.

The first random event occurred on October 12 beneath Umtanum Ridge. This was a very small event (approximately $0.0 \mathrm{M}_{\mathrm{c}}$ ) that occurred in the crystalline basement.

Two random events occurred on November 10 on the Horse Heaven Hills southwest of Prosser, Washington. Both were deep events (>8 km) and had magnitudes of $2.6 \mathrm{M}_{\mathrm{c}}$ and $1.2 \mathrm{M}_{\mathrm{c}}$, respectively.

On December 4, a small (approximately $0.0 \mathrm{M}_{\mathrm{c}}$ ) earthquake occurred in the crystalline basement ( $>17 \mathrm{~km}$ depth) southeast of the crest of Rattlesnake Mountain. 
Two small (approximately $0.0 \mathrm{M}_{\mathrm{c}}$ ) random earthquakes occurred in the pre-basalt sediment beneath Cold Creek north of Yakima Ridge on December 19.

The last random event for the first quarter of FY 2006 occurred north of Rattlesnake Mountain. It was small (approximately 0.0 Mc) and in the basalt. Because this earthquake is north of the Rattlesnake Mountain fault and not near any mapped fault, we classify this event as random. 


\subsection{Strong Motion Accelerometer Operations}

The Hanford SMA network has been in continuous operation since November 20, 1998. The nominal threshold used in the SMA network is $0.001 \mathrm{~g}$ in order to provide ground motion for smaller, nondamaging earthquakes that can be useful in estimating the ground motion expected from larger earthquakes, and to confirm correct operation of the instruments by analyzing the smaller-amplitude triggers (see Section 2.2).

\subsection{FY 2006 Triggers of the Hanford SMA Network}

The Hanford SMA network did not trigger from a seismic event during the first quarter of FY 2006. 


\subsection{Capabilities in the Event of a Significant Earthquake}

The SMA network was designed to provide ground motion data in areas at the Hanford Site that have high densities of people and/or facilities containing hazardous materials in order to insure the Hanford Site is in compliance with DOE Order 420.1, "Facility Safety." The network also allows the HSAP to support Hanford Site emergency services organizations in complying with DOE Order G 420.1-1, Section 4.7, "Emergency Preparedness and Emergency Communications,” by providing area ground motion data in the event of an earthquake on the Hanford Site. This section summarizes the capabilities of the HSAT in the event of an earthquake at Hanford.

\subsection{Use of the SMA Network in the Event of an Earthquake}

Historically, only a few facilities at the Hanford Site had instruments to provide data on peak ground accelerations or any type of ground motion. The present SMA instruments were located so that if an earthquake occurred, ground motion data would be readily available to assess the damage at the 100-K Area, the 200-East and West Areas, and the 300 and 400 Area facilities, which have the greatest concentration of people and also contain hazardous materials (Moore and Reidel 1996).

Many facilities at the Hanford Site have undergone various degrees of seismic analysis either during design or during re-qualification. Although the seismic design of a building may be known, when an earthquake is "felt" in a facility on the Hanford Site, a determination must be made as to the extent of damage before it can be re-occupied and the systems restarted. A "felt" earthquake may not cause any significant damage to a building but, without adequate characterization of the ground motion, initial determination of the building's possibility of having damage may be impossible.

In the event of an earthquake such as the 2001 Nisqually earthquake, building managers, emergency directors, and engineers can obtain ground motion data recorded by the SMA network from the HSAT in the Sigma V Building. This is done through the Hanford Site Emergency Services Organization. Normal hours of operation for the HSAP are between 6 a.m. and 4:30 p.m., Monday through Friday. If a SMA is triggered, the HSAT will download events that were recorded and determine the peak ground accelerations. This information is then passed on to Hanford Emergency Services personnel where the facility engineers can use the data to determine if the ground motion exceeded, is equal to, or is less than the building design. This, along with assessments from trained engineers, allows the facility manager to make a rapid and cost-effective determination on whether a building is safe to re-occupy or should not be used until it has been inspected in more detail. Buildings that have designs exceeding the recorded ground motion could be put back into service very quickly; buildings with designs that are very close to or less than measured ground motion could be given priority for onsite damage inspections. 


\subsection{References}

Campbell NP. 1989. "Structural and Stratigraphic Interpretation of Rocks under the Yakima Fold Belt, Columbia Basin, Based on Recent Surface Mapping and Well Data.” In SP Reidel and PR Hooper (eds.), Volcanism and Tectonism in the Columbia River Flood-Basalt Province Geological Society of America Special Paper 239, pp. 209-222.

Crosson RS. 1972. Small Earthquakes, Structure and Tectonics of the Puget Sound Region. Bulletin of the Seismological Society of America 62(5):1133-1171.

DOE. 1988. Site Characterization Plan for the Reference Location, Hanford, Washington-Consultation Draft. Report DOE/RW-0164, Vol. 1, U.S. Department of Energy, Washington, D.C.

DOE Order 420.1. “Facility Safety.”

DOE Order G 420.1-1, Section 4.7. “Emergency Preparedness and Emergency Communications.”

Fenneman NM. 1931. Physiography of Western United States. McGraw-Hill, 534 p.

Geomatrix. 1996. Probabilistic Seismic Hazard Analysis, DOE Hanford Site, Washington. WHC-SDW236A-TI-002, Rev. 1, Westinghouse Hanford Company, Richland, Washington.

Moore C and SP Reidel. 1996. Hanford Site Seismic Monitoring Instrumentation Plan. WHC-SD-GNER-30036, Westinghouse Hanford Company, Richland, Washington.

Reidel SP and KR Fecht. 1994a. Geologic Map of the Richland 1:100,000 Quadrangle, Washington. Washington Division of Geology and Earth Resources Open File Report 94-8, 21 p., 1 plate.

Reidel SP and KR Fecht. 1994b. Geologic Map of the Priest Rapids 1:100,000 Quadrangle, Washington. Washington Division of Geology and Earth Resources Open File Report 94-13, 22 p., 1 plate.

Reidel SP and PR Hooper (eds.). 1989. Volcanism and Tectonism in the Columbia River Flood-Basalt Province Geological Society of America Special Paper 239, 386 p.

Reidel SP, NP Campbell, KR Fecht, and KA Lindsey. 1994. "Late Cenozoic Structure and Stratigraphy of South-Central Washington.” In E Cheney and R Lasmanis (eds.), Regional Geology of Washington State, Washington Division of Geology and Earth Resources Bulletin 80, pp. 159-180, Olympia, Washington.

Reidel SP, KR Fecht, MC Hagood, and TL Tolan. 1989. "Geologic Development of the Central Columbia Plateau.” In SP Reidel and PR Hooper (eds.), Volcanism and Tectonism in the Columbia River Flood-Basalt Province Geological Society of America Special Paper 239, pp. 247-264.

Richter CF. 1958. Elementary Seismology, W. H. Freeman and Company, p. 768. 
Rohay AC, DW Glover, and SD Malone. 1985. Time-Term Analysis of Upper Crustal Structure in the Columbia Basin, Washington. RHO-BW-SA-435 P, Rockwell Hanford Operations, Richland, Washington. 


\section{Distribution}

No. of

\section{Copies}

\section{OFFSITE}

Administrator

Kennewick General Hospital

P.O. Box 6128

Kennewick, WA 99336

Dr. R. Carson

Department of Geology

Whitman College

345 Bayer Avenue

Walla Walla, WA 99362

T. Conrads

Parsons Constructors, Inc.

3005 E. Ainsworth Street

Pasco, WA 99301

G. Crawford

Earthquake Program Manager

Washington Emergency Management

Division

Building 20, M/S: TA-20

Camp Murray, WA 98430-5122

Idaho Geological Survey

Morrill Hall

University of Idaho

P.O. Box 443014

Moscow, ID 83844-3014

J. Kimball

NNSA NA 2.1

19901 Germantown Road

Germantown, MD 20874
No. of

Copies

S. Lilligren

Nez Perce Tribe

P.O. Box 365

Lapwai, ID 83540

J. Litehiser

Bechtel National, Inc.

P.O. Box 193965

San Francisco, CA 94119-3965

2 Oregon Department of Geology and

Mineral Industries

Suite 965, 800 NE Oregon Street \#28

Portland, OR 97232

ATTN: Library

$$
\text { I. Madin }
$$

N. Rasmussen

3140 Ravenshoe Drive

Las Vegas, NV 89134

P. Rizzo

105 Mall Boulevard

Monroeville, PA 15146

M. Stickney

Montana Tech University

Earthquake Studies Office

Butte, MT 59701

A. Tallman 1940 Quail Court

West Richland, WA 99353 
No. of

Copies

4 University of Washington

Geophysics Program

P.O. Box 351650

Seattle, WA 98195-1650

ATTN: R. Crosson

R. Ludwin

S. Malone

R. Steele

2 University of Washington

U.S. Geological Survey

P.O. Box 351650

Seattle, WA 98195

ATTN: C. Weaver

T. Yelin

U.S. Fish and Wildlife Service

3250 Port of Benton Boulevard

Richland, WA 99352

2 U.S. Geological Survey

Mail Stop 977

345 Middlefield Road

Menlo Park, CA 94025

ATTN: T. Brocher

3 Washington Division of Geology and Earth Resources

P.O. Box 47007

Olympia, WA 98504-7007

ATTN: Library

T. Walsh

Washington State University

Department of Geology

P.O. Box 643420

Pullman, WA 99164-2812
No. of

Copies

R. Whale

Shell E\&P

200 N. Dairy Ashford

Houston, TX 77079

I. G. Wong

URS Corporation

1333 Broadway, Suite 800

Oakland, CA 94612

J. Zollweg

Boise State University

Department of Geosciences

Boise, ID 83725

\section{ONSITE}

7 DOE Richland Operations Office

B. L. Charboneau A6-33

K. L. Flynn A6-35

R. D. Hildebrand A6-38

L. F. Miller H6-60

M. R. Moreno H6-60

J. G. Morse A6-38

Y. T. Sherman A6-35

K. M. Thompson A6-38

Bechtel Hanford, Inc.

K. R. Fecht H9-01

5 CH2M HILL Hanford Group, Inc.

F. J. Anderson H6-03

D. D. Bachland $\quad$ S5-15

C. Defigh-Price R2-58

J. R. Freeman-Pollard R3-77

D. T. Heimberger $\quad$ S5-25

F. M. Mann H6-03 
No. of

Copies

Duratek Federal Services Hanford

R. T. Wilde

H8-44

9 Fluor Hanford, Inc.

M. E. Brown

D. A. Conners

J. T. Curtis

S. A. Fargo

S. M. Faulk

B. H. Ford

T. P. Morales

M. I. Wood

M. T. York

\section{Stoller}

R. McCain

B2-62
No. of

Copies

\section{Washington State Department of Ecology}
J. Caggiano
H0-57

16 Pacific Northwest National Laboratory

R. E. Clayton K6-75

J. S. Fruchter K6-96

D. C. Hartshorn K6-75

D. G. Horton K6-75

P. E. Moore J2-09

B. E. Opitz K6-75

S. P. Reidel (5) K6-75

A. C. Rohay K6-75

H. T. Schaef K6-81

M. D. Sweeney K6-75

Hanford Technical Library (2) P8-55 